\title{
Flavonoid Glycosides from the Aerial Parts of Polygonatum odoratum (Mill.) Druce Growing in Mongolia
}

\author{
Chunsriimyatav Ganbaatar ${ }^{1,2}$, Margit Gruner $^{1}$, Dumaa Mishig ${ }^{2}$, Regdel Duger $^{2}$, Arndt W. Schmidt ${ }^{1}$ \\ and Hans-Joachim Knölker, ${ }^{1, *}$
}

${ }^{1}$ Department Chemie, Technische Universität Dresden, Bergstrasse 66, 01069 Dresden, Germany; ${ }^{2}$ Institute of Chemistry and Chemical Technology, Mongolian Academy of Sciences, Ulaanbaatar-210351, Mongolia

\begin{abstract}
We describe the isolation, identification, and structural elucidation of natural products from the Mongolian medicinal plant Polygonatum odoratum (Mill.) Druce. Six flavonoid glycosides, isorhamnetin-3-O-rutinoside (narcissoside, narcissin) (1), kaempferol-3- $O$-rutinoside (nicotiflorin) (2), quercetin-3- $O$-rutinoside (rutin) (3), apigenin-6- $C$ - $\beta$-Dglucoside (isovitexin) (4), apigenin-6-C-(2"- $O$ - $\beta$-D-xylopyranosyl- $\beta$-D-glucopyranoside) (desmodin) (5), and isovitexin-7$O-\beta$-D-glucoside (saponarin) (6), were isolated from the aerial parts of Polygonatum odoratum (Mill.) Druce. The structures of 1-6 have been confirmed by UV, IR, MS, and NMR $\left({ }^{1} \mathrm{H},{ }^{13} \mathrm{C}\right.$, COSY, HSQC, HMBC, NOESY, and ROESY) data.
\end{abstract}

Graphical Abstract:
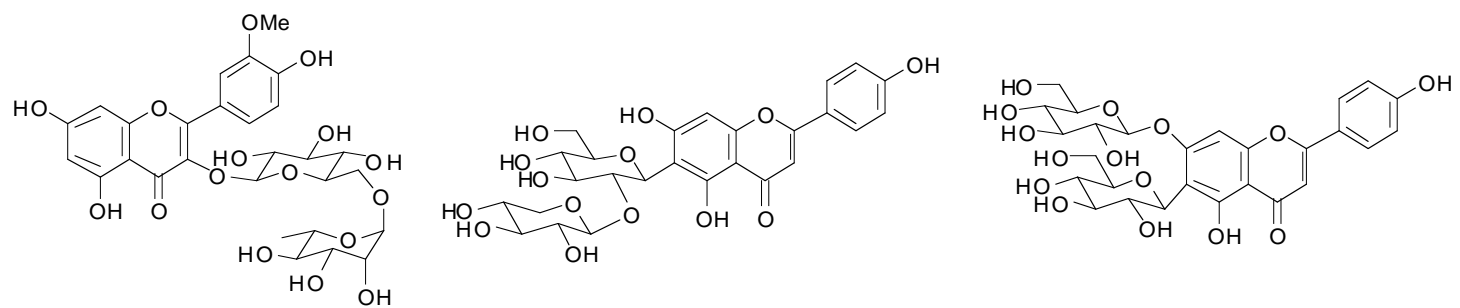

Keywords: Flavonoid glycosides, mongolian medicinal plants, NMR spectroscopy, Polygonatum odoratum.

\section{INTRODUCTION}

In the flora of Mongolia, three species of Polygonatum: $P$. odoratum, $P$. sibiricum, and $P$. humile, have been reported [1]. Polygonatum, a genus of approximately 63 species, belongs to the family Asparagaceae which is widely distributed from Asia to Europe [2]. Polygonatum odoratum is used in traditional Mongolian medicine for the treatment of weakness, impotence, diseases of the kidneys, gonorrhea, pains in the back and legs, coughing, tuberculosis, yellow liquorstasis, and diabetes [3]. Previous phytochemical studies on this species revealed the presence of steroidal saponins [4-6], sterols [6], homoisoflavonoids [7-10], and cholestane glycosides [11]. In the present study, we report the isolation and structural elucidation of six flavonoid glycosides from the aerial parts of $P$. odoratum (Mill.) Druce collected in Mongolia, five of them were obtained from this plant for the first time.

\section{RESULTS AND DISCUSSION}

A detailed investigation of the ethyl acetate extract of the aerial parts of $P$. odoratum (Mill.) Druce led to the isolation

*Address correspondence to this author at the Department Chemie, Technische Universität Dresden, Bergstrasse 66, 01069 Dresden, Germany; Tel: +49 351-463-34659; Fax: +49 351-463-37030;

E-mail: hans-joachim.knoelker@tu-dresden.de of six flavonoid glycosides. These were identified as isorhamnetin-3-O-rutinoside (1), kaempferol-3- $O$-rutinoside (2), quercetin-3- $O$-rutinoside (rutin) (3), apigenin-6- $C$ - $\beta$-D-glucoside (isovitexin) (4), apigenin-6- $C$ - $\left(2^{\prime \prime}-O-\beta\right.$-D-xylopyranosyl- $\beta$-Dglucopyranoside) (desmodin) (5), and isovitexin-7- $O-\beta$-Dglucoside (saponarin) (6) [7] (Fig. 1).

Compounds 1-5 were isolated from $P$. odoratum for the first time. The chemical structures of the compounds 1-6 were elucidated by their UV, IR, ESI-MS, and ${ }^{1} \mathrm{H}$ and ${ }^{13} \mathrm{C}$ NMR data. The UV spectra of compounds 1, 2, and $\mathbf{3}$ exhibited similar absorption bands at $\lambda=266,310$, and $352 \mathrm{~nm}$, indicating a $\mathrm{C} 3-O$-substituted flavonol skeleton, whereas the UV spectra of compounds $\mathbf{4}, \mathbf{5}$, and $\mathbf{6}$ showed absorption maxima at $\lambda=331-337 \mathrm{~nm}$ and $271-272 \mathrm{~nm}$ [12-14]. The IR spectra of compounds 1-6 showed similar maximum absorption bands at $v=3369-3306 \mathrm{~cm}^{-1}$ (hydroxyl groups), 1658$1603 \mathrm{~cm}^{-1}$ (carbonyl group) and a broad band at $v=1180$ $1060 \mathrm{~cm}^{-1}$, indicating its glycosidic nature [15].

Compound 1 was obtained as a yellow powder. The ESIMS showed an $[\mathrm{M}+\mathrm{H}]^{+}$ion at $m / z=625$. The MS and the ${ }^{13} \mathrm{C}$ NMR data (Table 1) suggested a molecular formula of $\mathrm{C}_{28} \mathrm{H}_{32} \mathrm{O}_{16}$. The ${ }^{1} \mathrm{H}$ NMR spectrum showed two doublets at $\delta_{\mathrm{H}}=6.26(\mathrm{~d}, J=2.0 \mathrm{~Hz}, 1 \mathrm{H})$ and $\delta_{\mathrm{H}}=6.46(\mathrm{~d}, J=2.0 \mathrm{~Hz}, 1$ $\mathrm{H})$ which correlated with the carbon signals at $\delta_{\mathrm{C}}=99.96$ 
and 94.90 in the HSQC spectrum. Thus, the positions of these two protons at $\mathrm{C} 6$ and $\mathrm{C} 8$ of the 5,7-dihydroxysubstituted A-ring of the flavonoid framework were confirmed (Fig. 2). A doublet of doublets at $\delta_{\mathrm{H}}=7.67$ (dd, $J=$ $8.4,2.0 \mathrm{~Hz})$ and two doublets at $\delta_{\mathrm{H}}=6.96(\mathrm{~J}=8.4 \mathrm{~Hz})$ and $7.99(J=2.0 \mathrm{~Hz})$ were assigned as $\mathrm{C}^{\prime}{ }^{\prime}-\mathrm{H}, \mathrm{C} 5^{\prime}-\mathrm{H}$, and $\mathrm{C} 2^{\prime}-\mathrm{H}$ of the B-ring. Additionally, the ${ }^{1} \mathrm{H}$ NMR spectrum exhibited one singlet at $\delta_{\mathrm{H}}=3.99(3 \mathrm{H})$, indicating the presence of a methoxy group, which showed a correlation with the carbon resonance at $\delta_{\mathrm{C}}=148.34\left(\mathrm{C}^{\prime}\right)$ in the $\mathrm{HMBC}$ spectrum. The doublets at $\delta_{\mathrm{H}}=5.29(\mathrm{~d}, J=7.5 \mathrm{~Hz})$ and $\delta_{\mathrm{H}}=4.57(\mathrm{~d}, J=1.4$ $\mathrm{Hz}$ ) were attributed to the anomeric protons of the glucosyl and rhamnosyl moieties, respectively. The homonuclear correlation spectrum NOESY showed a spatial coupling between the aromatic hydrogen atom $\mathrm{C} 2{ }^{\prime}-\mathrm{H}\left(\delta_{\mathrm{H}}=7.99\right)$ and the methoxy hydrogen atoms, suggesting that the methoxy group is at C3'. This assignment was corroborated by the HMBC spectrum which exhibited a three-bond long-range coupling of the methoxy group $\left(\delta_{\mathrm{H}}=3.99\right)$ with $\mathrm{C} 3^{\prime}\left(\delta_{\mathrm{C}}=148.34\right)$. Analysis of the one- and two-dimensional ${ }^{1} \mathrm{H}$ and ${ }^{13} \mathrm{C}$ NMR spectra of $\mathbf{1}$ and comparison with the values found in the literature [16] led to the assignment of compound $\mathbf{1}$ as isorhamnetin-3-O-rutinoside. It has been reported previously that isorhamnetin-3-O -rutinoside (1) shows antiproliferative and antioxidative activities $[17,18]$.
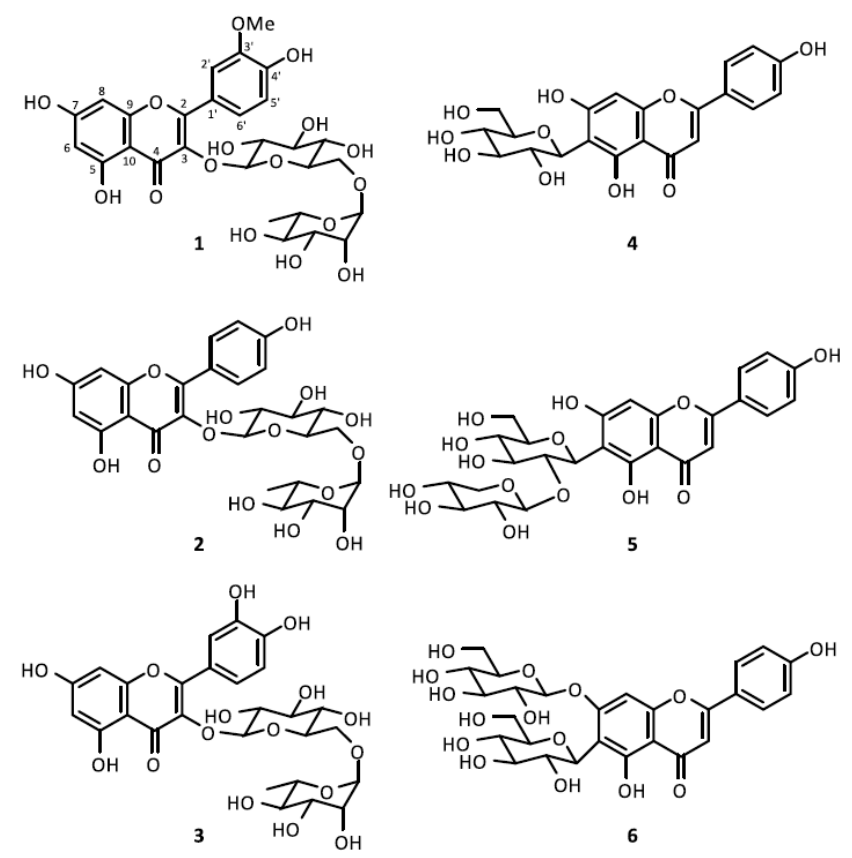

Fig. (1). Structures of the flavonoid glycosides 1-6 isolated from $P$. odoratum (Mill.) Druce.

Compound $\mathbf{2}$ was isolated as a yellow powder. The $[\mathrm{M}+\mathrm{H}]^{+}$ion at $m / z=595$ in the ESI-MS together with the ${ }^{13} \mathrm{C}$ NMR data (Table 1) indicated a molecular formula of $\mathrm{C}_{27} \mathrm{H}_{30} \mathrm{O}_{15}$. The aliphatic signals in the ${ }^{1} \mathrm{H}$ and ${ }^{13} \mathrm{C} \mathrm{NMR}$ spectra of $\mathbf{2}$ were similar to those of $\mathbf{1}$, except for the absence of the signals of a methoxy group. The aromatic region in the ${ }^{1} \mathrm{H}$ NMR spectrum of $\mathbf{2}$ in methanol- $d_{4}$ showed signals characteristic for kaempferol: $\delta_{\mathrm{H}}=6.25(\mathrm{~d}, J=2.1 \mathrm{~Hz}, \mathrm{C} 6-\mathrm{H})$, $6.45(\mathrm{~d}, J=2.1 \mathrm{~Hz}, \mathrm{C} 8-\mathrm{H}), 6.93\left(\mathrm{~d}, J=8.9 \mathrm{~Hz}, \mathrm{C} 3^{\prime}-\mathrm{H}\right.$ and C5'-H), and $8.11\left(\mathrm{~d}, J=8.9 \mathrm{~Hz}, \mathrm{C}^{\prime}-\mathrm{H}\right.$ and $\left.\mathrm{C}^{\prime}-\mathrm{H}\right)$. The sig- nals for the anomeric protons of the glucosyl and rhamnosyl units appear at $\delta_{\mathrm{H}}=5.17\left(\mathrm{~d}, J=7.4 \mathrm{~Hz}, \mathrm{C} 1{ }^{\prime \prime}-\mathrm{H}\right)$ and $4.56(\mathrm{~d}$, $\left.J=1.4 \mathrm{~Hz}, \mathrm{C}^{\prime \prime \prime}-\mathrm{H}\right)$. In the HMBC spectrum, the signal of one of the glucosyl hydrogen atoms $\left(\delta_{\mathrm{H}}=3.85, \mathrm{C6}^{\prime \prime}-\mathrm{H}_{\mathrm{a}}\right)$ correlated with the signal at $\delta_{\mathrm{C}}=102.43$ (rhamnose $\mathrm{C1}^{\prime \prime \prime}$ ) indicating a rutinosyl moiety. Finally, the signal of the glucosyl C1"-hydrogen atom $\left(\delta_{\mathrm{H}}=5.17\right)$ correlated with $\mathrm{C} 3$ of the flavonoid unit $\left(\delta_{\mathrm{C}}=135.51\right)$ in the HMBC spectrum. Analysis of the one- and two-dimensional ${ }^{1} \mathrm{H}$ and ${ }^{13} \mathrm{C}$ NMR spectra of 2 and comparison with the values found in the literature $[19,20]$ identified compound $\mathbf{2}$ as kaempferol-3- $O$-rutinoside. It has been reported that kaempferol-3- $O$-rutinoside (2) shows strong antioxidant activity [21] and causes a remarkable decrease in arterial blood pressure and heart rate [22].

Compound 3 was obtained as a yellow powder. The ESIMS with an $[\mathrm{M}+\mathrm{Na}]^{+}$ion at $\mathrm{m} / z=633$ together with the ${ }^{13} \mathrm{C}$ NMR and HMBC data (Table 1) indicated a molecular formula of $\mathrm{C}_{27} \mathrm{H}_{30} \mathrm{O}_{16}$. The ${ }^{1} \mathrm{H}$ NMR spectrum of compound 3 was similar to that of compound 1, except for the absence of the signal for a methoxy group, and showed the characteristic signals of the quercetin skeleton: $\delta_{\mathrm{H}}=6.26(\mathrm{~d}, J=2.1 \mathrm{~Hz}$, C6-H), 6.45 (d, $J=2.1 \mathrm{~Hz}, \mathrm{C} 8-\mathrm{H}), 7.68(\mathrm{dd}, J=8.4,2.2 \mathrm{~Hz}$, C6'-H), $6.92\left(\mathrm{~d}, J=8.4 \mathrm{~Hz}, \mathrm{C}^{\prime}-\mathrm{H}\right)$, and $7.71(\mathrm{~d}, J=2.2 \mathrm{~Hz}$, $\left.\mathrm{C} 2{ }^{\prime}-\mathrm{H}\right)$. In the HMBC spectrum, the rhamnosyl $\mathrm{C}^{\prime \prime \prime}$ hydrogen atom $\left(\delta_{\mathrm{H}}=4.56\right)$ correlated with the glucosyl C6" atom at $\delta_{\mathrm{C}}=68.5$ indicating a rutinosyl moiety. Finally, the glucosyl C1"-hydrogen atom $\left(\delta_{\mathrm{H}}=5.15\right)$ correlated with $\mathrm{C} 3$ $\left(\delta_{\mathrm{C}}=135.62\right)$ of the flavonoid unit in the HMBC spectrum. The analysis of the one- and two-dimensional ${ }^{1} \mathrm{H}$ and ${ }^{13} \mathrm{C}$ NMR spectra of $\mathbf{3}$ and comparison with the values found in the literature $[16,19,20]$ led to the assignment of compound 3 as quercetin-3- $O$-rutinoside (rutin). A strong antioxidant activity has been found for compound $\mathbf{3}$ in several assay systems [21-23].

Compound 4 was isolated as a yellow powder. The ESIMS with an $[\mathrm{M}+\mathrm{H}]^{+}$ion at $m / z=433$ and the ${ }^{13} \mathrm{C}$ NMR and HMBC data (Table 2) suggested a molecular formula of $\mathrm{C}_{21} \mathrm{H}_{20} \mathrm{O}_{10}$. The ${ }^{1} \mathrm{H}$ NMR spectrum of 4 showed a singlet resonance at $\delta_{\mathrm{H}}=6.53$ assigned to the proton at $\mathrm{C} 8$ of the $\mathrm{A}$ ring, based on the long-range correlations observed between this proton and $\mathrm{C} 10\left(\delta_{\mathrm{C}}=105.19\right), \mathrm{C} 7\left(\delta_{\mathrm{C}}=165.0\right)$, and $\mathrm{C} 9$ $\left(\delta_{\mathrm{C}}=158.74\right)$ in the HMBC spectrum. Two doublets with $J=$ $8.7 \mathrm{~Hz}$ at $\delta_{\mathrm{H}}=7.87(2 \mathrm{H})$ and $6.96(2 \mathrm{H})$ were assigned as the $\mathrm{C}^{\prime} / \mathrm{C}^{\prime}$ and $\mathrm{C}^{\prime} / \mathrm{C}^{\prime}$ ' protons of the para-substituted $\mathrm{B}$ ring. A singlet proton resonance at $\delta_{\mathrm{H}}=6.63$, which correlated with the carbon resonance at $\delta_{\mathrm{C}}=103.88$ in the HSQC spectrum, was assigned to the $\mathrm{C} 3-\mathrm{H}$ of the flavonoid unit. In the HMBC spectrum of 4 , a prominent long-range correlation between the anomeric proton $\mathrm{C} 1 "-\mathrm{H}\left(\delta_{\mathrm{H}}=4.95\right)$ of the glucosyl moiety and C6 $\left(\delta_{\mathrm{C}}=109.19\right)$ of the flavonoid unit showed the attachment of the sugar at $\mathrm{C} 6$ by a $\mathrm{C}-\mathrm{C}$ linkage. Analysis of the one- and two-dimensional ${ }^{1} \mathrm{H}$ and ${ }^{13} \mathrm{C} \mathrm{NMR}$ spectra of 4 and comparison with the values found in the literature [19, 24-26] identified compound 4 as apigenin-6- $C$ $\beta$-D-glucoside (isovitexin). Various biological activities have been found for isovitexin (4) such as hypotensive, antiinflammatory, antispasmodic, antimicrobial, antioxidant/free radical scavenging activity, as well as radioprotective effects [27], and antihyperglycemic activity [28]. 
Table 1. ${ }^{1} \mathrm{H}(600 \mathrm{MHz})$ and ${ }^{13} \mathrm{C}(150 \mathrm{MHz})$ NMR spectroscopic data of 1, 2 and 3 (solvent: methanol- $\left.d_{4}\right)$.

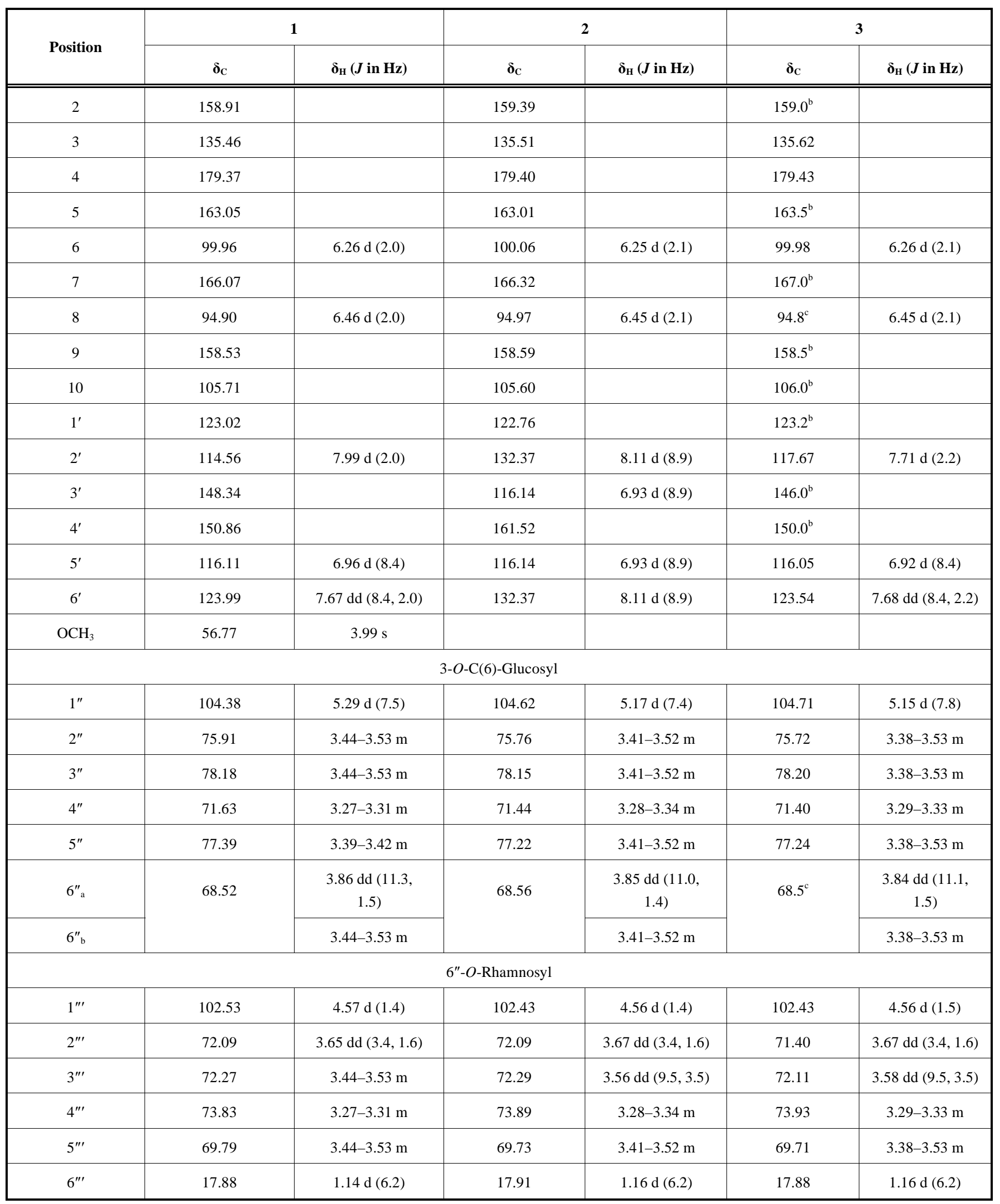

${ }^{a}$ Numbering of the flavonoid framework: see Fig. (2).

${ }^{b}$ Chemical shift based on the HMBC spectrum (see Supplementary Information).

${ }^{\mathrm{c}}$ Chemical shift based on the HSQC spectrum (see Supplementary Information). 


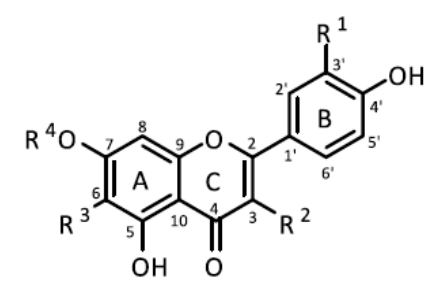

\begin{tabular}{|c|c|c|c|c|c|}
\hline Compound & Flavonoid & $\mathbf{R}^{1}$ & $\mathbf{R}^{2}$ & $\mathbf{R}^{3}$ & $\mathbf{R}^{4}$ \\
\hline 1 & Isorhamnetin & $\mathrm{OCH}_{3}$ & O- $[\alpha-\mathrm{L}-\mathrm{Rha}-(1 \rightarrow 6)-\beta$-D-Glc $]$ & $\mathrm{H}$ & $\mathrm{H}$ \\
\hline 3 & Quercetin & $\mathrm{OH}$ & O- $[\alpha-\mathrm{L}-\mathrm{Rha}-(1 \rightarrow 6)-\beta$-D-Glc $]$ & $\mathrm{H}$ & $\mathrm{H}$ \\
\hline 4 & Apigenin & $\mathrm{H}$ & $\mathrm{H}$ & $\beta$-D-Glc & $\mathrm{H}$ \\
\hline 6 & Apigenin & $\mathrm{H}$ & $\mathrm{H}$ & $\beta$-D-Glc & $\beta$-D-Glc \\
\hline
\end{tabular}

Fig. (2). Numbering of the flavonoid framework for the compounds 1-6.

Compound $\mathbf{5}$ was isolated as a light yellow powder. The ESI-MS with an $[\mathrm{M}+\mathrm{H}]^{+}$ion at $m / z=565$ together with the ${ }^{13} \mathrm{C}$ NMR, HMBC and HSQC data (Table 2) suggested a molecular formula of $\mathrm{C}_{26} \mathrm{H}_{28} \mathrm{O}_{14}$. The NMR data of compound 5 indicated that the flavonoid unit was the same as that of compound 4. The $\mathrm{C}-\mathrm{C}$ linkage of the 6-C-glucosyl unit was confirmed by the $\mathrm{HMBC}$ cross peaks at $\delta_{\mathrm{H}}=6.54 /$ $\delta_{\mathrm{C}}=73.55\left(\mathrm{C} 8-\mathrm{H} / \mathrm{C} 1^{\prime \prime}\right)$ and $\delta_{\mathrm{H}}=6.54 / \delta_{\mathrm{C}}=108.9(\mathrm{C} 8-\mathrm{H} /$ C6). The downfield shift of $\mathrm{C}^{2 \prime}-\mathrm{H}$, a very broad signal at $\delta_{\mathrm{H}}$ $=4.4$ identified in the HSQC and HMBC spectra, indicated a 1,2-glycosidic linkage between the C-glucosyl and the xylosyl unit. Analysis of the one- and two-dimensional ${ }^{1} \mathrm{H}$ and ${ }^{13} \mathrm{C}$ NMR spectra of compound $\mathbf{5}$ and comparison with the values found in the literature [29-31] led to the assignment as apigenin-6-C-(2"-O- $\beta$-D-xylopyranosyl- $\beta$-D-glucopyrano-side) (desmodin).

Compound 6 was isolated as a light yellow powder. The $[\mathrm{M}+\mathrm{H}]^{+}$ion at $m / z=595$ in the ESI-MS together with the ${ }^{13} \mathrm{C}$ NMR, HMBC and HSQC data (Table 2) indicated a molecular formula of $\mathrm{C}_{27} \mathrm{H}_{30} \mathrm{O}_{15}$. The ${ }^{1} \mathrm{H}$ NMR spectrum showed two doublets $(J=8.9 \mathrm{~Hz})$ at $\delta_{\mathrm{H}}=7.83\left(\mathrm{C} 2^{\prime}-\mathrm{H} / \mathrm{C} 6^{\prime}-\mathrm{H}\right)$ and $6.77\left(\mathrm{C}^{\prime}-\mathrm{H} / \mathrm{C}^{\prime}-\mathrm{H}\right)$, which correlated with the carbon signals at $\delta_{\mathrm{C}}=130.0\left(\mathrm{C} 2^{\prime} / \mathrm{C} 6^{\prime}\right)$ and $120.0\left(\mathrm{C}^{\prime} / \mathrm{C}^{\prime}\right)$, and two singlets at $\delta_{\mathrm{H}}=6.61(\mathrm{C} 3-\mathrm{H})$ and $6.95(\mathrm{C} 8-\mathrm{H})$, which correlated with the carbon signals at $\delta_{\mathrm{C}}=102.1(\mathrm{C} 3)$ and 95.2 (C8) in the HSQC spectrum. For the sugar moieties, the HMBC spectrum showed the following correlations of the anomeric protons: $\mathrm{C} 1{ }^{\prime \prime}-\mathrm{H}\left(\delta_{\mathrm{H}}=4.96\right)$ with $\mathrm{C} 6\left(\delta_{\mathrm{C}}=110.1\right)$ and $\mathrm{C} 1^{\prime \prime \prime}-\mathrm{H}\left(\delta_{\mathrm{H}}\right.$ $=5.12)$ with $\mathrm{C} 7\left(\delta_{\mathrm{C}}=164.0\right)$. These correlations indicated that the first glucosyl unit $\left(\mathrm{Cl}^{\prime \prime}-\mathrm{H}\right)$ was attached to the flavonoid framework at $\mathrm{C} 6$ and the second glucosyl unit (C1"'$\mathrm{H})$ at the flavonoid C7-oxygen atom. This assignment has been supported by a HMBC correlation of the glucosyl C2"$\mathrm{H}$ and $\mathrm{C} 6$ of the flavonoid skeleton. Additional structural support derived from the following cross peaks in ROESY and NOESY experiments: C3-H/C2'-H (C6'-H), C8-H/C2'-H $\left(\mathrm{C} 66^{\prime}-\mathrm{H}\right), \mathrm{C} 1^{\prime \prime \prime}-\mathrm{H} / \mathrm{C} 8-\mathrm{H}$, and $\mathrm{C} 2{ }^{\prime \prime \prime}-\mathrm{H} / \mathrm{C} 8-\mathrm{H}$. Based on these observations the structure of compound $\mathbf{6}$ was determined as isovitexin-7- $O-\beta$-D-glucoside (saponarin) [7]. This assign- ment was additionally supported by the one- and twodimensional NMR spectra in DMSO- $d_{6}$ as solvent and their comparison with the data reported in the literature (see Supplementary Information) [32, 33].

\section{EXPERIMENTAL}

\subsection{General}

Optical rotations were measured with a Perkin-Elmer 341 polarimeter at a wavelength of $589 \mathrm{~nm}$ (sodium D line) using a 1.0-decimeter cell with a total volume of $1.0 \mathrm{~mL}$. UV spectra were measured with a Perkin-Elmer Lambda $25 \mathrm{UV}-\mathrm{V}$ is spectrometer. IR data were obtained with a Thermo Nicolet Avatar 360 FT-IR spectrometer. The NMR spectra were recorded with a Bruker AVANCE III $600 \mathrm{MHz}$ spectrometer using methanol- $d_{4}$ as solvent. The chemical shifts $\delta$ are reported in ppm using the non-deuterated residual solvent as internal standard $\left(\delta_{\mathrm{H}}=3.35, \delta_{\mathrm{C}}=49.0\right)$. Coupling constants $J$ are given in $\mathrm{Hz}$. Complete assignments of the ${ }^{1} \mathrm{H}$ NMR and ${ }^{13} \mathrm{C}$ NMR signals were achieved by measuring the following $2 \mathrm{D}$ NMR spectra: COSY, HSQC, HMBC, NOESY, and ROESY. ESIMS spectra were recorded on a Bruker-Esquire LC mass spectrometer with an ion trap detector; positive and negative ions were detected. Thin layer chromatography was performed on silica gel $60 \mathrm{~F}_{254}$ (Merck). Preparative TLC was performed with glass plates $(20 \times 20 \mathrm{~cm}$, Merck) coated with a $0.25 \mathrm{~mm}$ layer of silica gel $\left(60-\mathrm{F}_{254}\right)$, mobile phase $\mathrm{EtOAc} / \mathrm{EtOH} / \mathrm{H}_{2} \mathrm{O}$ $(77: 15: 8)$. Sequential treatment with a solution of 2aminoethyl diphenylborinate in methanol (1 wt- $\%)$ and poly(ethylene glycol) BioUltra 4000 in ethanol (5 wt-\%) or treatment with sulfuric acid (5 vol-\% in ethanol) and subsequent heating with a hot air gun were used for visualization.

\subsection{Plant Material}

The aerial parts of $P$. odoratum (Mill.) Druce were collected in July 2012 from Terelj, Mongolia. The plant was identified by Dr. Enebish Ganbold at the herbarium of the Ulaanbaatar Institute of Botany, Mongolian Academy of Sciences, where a voucher specimen has been deposited. 
Table 2. ${ }^{1} \mathrm{H}(600 \mathrm{MHz})$ and ${ }^{13} \mathrm{C}(150 \mathrm{MHz})$ NMR spectroscopic data of 4, 5 and 6 (solvent: methanol- $\left.d_{4}\right)$.

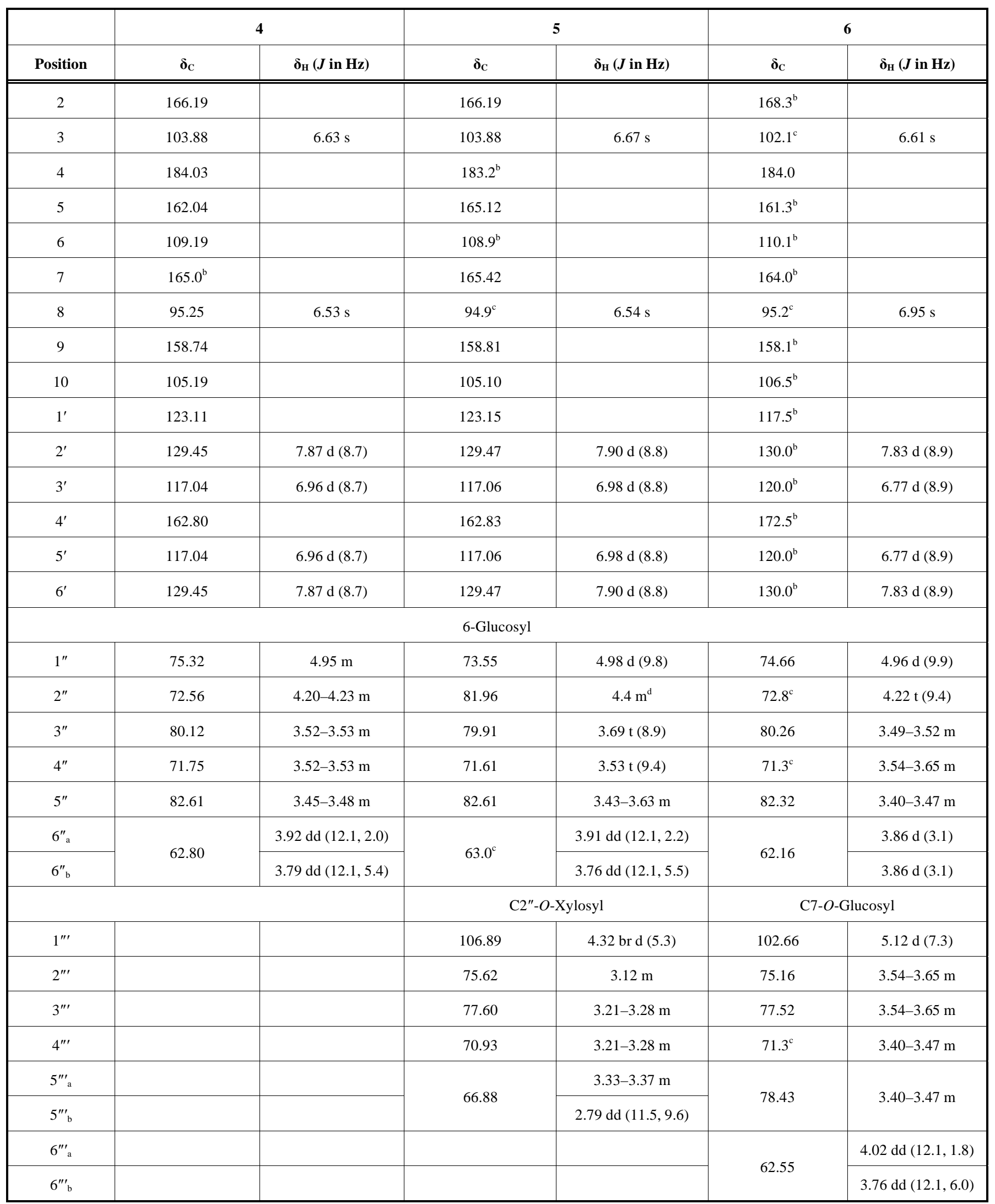

${ }^{\text {a }}$ Numbering of the flavonoid framework: see Fig. (2).

${ }^{\mathrm{b}}$ Chemical shift based on the HMBC spectrum (see Supplementary Information).

${ }^{\mathrm{c}}$ Chemical shift based on the HSQC spectrum (see Supplementary Information).

${ }^{\mathrm{d}}$ Very broad signal, assignment based on HSQC and HMBC experiments (see Supplementary Information). 


\subsection{Extraction and Isolation}

The air-dried and powdered aerial parts of the plant (1.0 $\mathrm{kg}$ ) were exhaustively extracted with $95 \%$ ethanol at room temperature. The extracts were combined and concentrated under reduced pressure to leave a residue, which was suspended in $\mathrm{H}_{2} \mathrm{O}$ and then fractionated by re-extracting with $\mathrm{n}$ hexane $(0.93 \mathrm{~g})$, chloroform $(10.97 \mathrm{~g})$, ethyl acetate $(8.39 \mathrm{~g})$, and n-butanol $(8.32 \mathrm{~g})$, respectively. The ethyl acetate extract $(4.0 \mathrm{~g})$ was subjected to column chromatography on silica gel (0.040-0.063 mm, Merck) and eluted with $\mathrm{CHCl}_{3} / \mathrm{MeOH}$ (gradient of 95:5 to 50:50) to afford 25 fractions based on the TLC profiles. Fraction $8(360 \mathrm{mg})$ was further purified by column chromatography on silica gel and eluted with $\mathrm{CHCl}_{3} / \mathrm{MeOH}$ (9:1, 6:1, and 3:1) to obtain five subfractions (F1-F5). Compound 4 was obtained from subfraction F1 by column chromatography on silica gel and elution with $\mathrm{CHCl}_{3} / \mathrm{MeOH}$ (6:1). Compounds $\mathbf{1}$ and $\mathbf{2}$ were isolated from subfraction $\mathrm{F} 2$ by preparative TLC developed with $\mathrm{EtOAc} / \mathrm{EtOH} / \mathrm{H}_{2} \mathrm{O}$ (77:15:8). Fraction 11 was further purified by preparative TLC with EtOAc/EtOH/ $\mathrm{H}_{2} \mathrm{O}(77: 15: 8)$ to provide compounds 3 and $\mathbf{5}$. Fractions 17-21 were further purified by preparative TLC with EtOAc/EtOH/ $\mathrm{H}_{2} \mathrm{O}$ $(77: 15: 8)$ to give compound $\mathbf{6}$.

3.4. Isorhamnetin-3-O-rutinoside (Narcissoside, Narcissin) (1)

Yellow powder; $R_{\mathrm{f}}=0.53\left(\right.$ EtOAc/EtOH $\left./ \mathrm{H}_{2} \mathrm{O}=77: 15: 8\right)$; $[\alpha]^{20}{ }_{\mathrm{D}}=-8.51$ (c 0.047, MeOH). UV (MeOH): $\lambda_{\max }=254$, 268 (sh), $298(\mathrm{sh}), 355 \mathrm{~nm}$. IR (ATR): $v=3351,2952,2923$, $1710,1658,1602,1499,1455,1355,1290,1204,1168$, 1127, 1018, 980, $804 \mathrm{~cm}^{-1} .{ }^{1} \mathrm{H}$ and ${ }^{13} \mathrm{C}$ NMR: see Table $\mathbf{1}$. ESI-MS $(+10 \mathrm{~V}): \mathrm{m} / \mathrm{z}=625[\mathrm{M}+\mathrm{H}]^{+}, 647[\mathrm{M}+\mathrm{Na}]^{+}$.

\subsection{Kaempferol-3- $O$-rutinoside (Nicotiflorin) (2)}

Yellow powder; $R_{\mathrm{f}}=0.59\left(\mathrm{EtOAc} / \mathrm{EtOH} / \mathrm{H}_{2} \mathrm{O}=77: 15: 8\right)$; $[\alpha]^{20}{ }_{\mathrm{D}}=-9.00$ (c 0.10, MeOH). UV (MeOH): $\lambda_{\max }=266$, 297 (sh), $349 \mathrm{~nm}$. IR (ATR): $v=3369,2952,2921,1709$, 1647, 1603, 1493, 1454, 1358, 1209, 1177, 1137, 1059, 885, $839,807 \mathrm{~cm}^{-1} .{ }^{1} \mathrm{H}$ and ${ }^{13} \mathrm{C}$ NMR: see Table 1. ESI-MS $(+25$ $\mathrm{V}): m / z=595[\mathrm{M}+\mathrm{H}]^{+}, 617[\mathrm{M}+\mathrm{Na}]^{+}$.

\subsection{Quercetin-3- $O$-rutinoside (Rutin) (3)}

Yellow powder; $R_{\mathrm{f}}=0.49\left(\mathrm{EtOAc} / \mathrm{EtOH} / \mathrm{H}_{2} \mathrm{O}=77: 15: 8\right)$; $[\alpha]^{20}{ }_{\mathrm{D}}=17.81(c 0.073, \mathrm{MeOH}) . \mathrm{UV}(\mathrm{MeOH}): \lambda_{\max }=257$, 268 (sh), 299 (sh), $354 \mathrm{~nm}$. IR (ATR): $v=3306,2949,2922$, $2850,1710,1648,1603,1495,1454,1357,1295,1199$, 1169, 1060, $807 \mathrm{~cm}^{-1} .{ }^{1} \mathrm{H}$ and ${ }^{13} \mathrm{C}$ NMR: see Table 1. ESIMS $(+50 \mathrm{~V}): m / z=633[\mathrm{M}+\mathrm{Na}]^{+}$.

\subsection{Apigenin-6- $\boldsymbol{C}$ - $\boldsymbol{\beta}$-D-glucoside (Isovitexin) (4)}

Yellow powder; $R_{\mathrm{f}}=0.65\left(\right.$ EtOAc/EtOH $\left./ \mathrm{H}_{2} \mathrm{O}=77: 15: 8\right)$; UV $(\mathrm{MeOH}): \lambda_{\max }=271,337 \mathrm{~nm}$. IR (ATR): $v=3320,2459$, $1604,1561,1509,1415,1332,1180,1019,972,820 \mathrm{~cm}^{-1}$. ${ }^{1} \mathrm{H}$ and ${ }^{13} \mathrm{C}$ NMR: see Table 2. ESI-MS $(+25 \mathrm{~V}): \mathrm{m} / \mathrm{z}=433$ $[\mathrm{M}+\mathrm{H}]^{+}$.
3.8. Apigenin-6- $C$-(2"- $O-\beta$-D-xylopyranosyl- $\beta$-Dglucopyranoside) (Desmodin) (5)

Light yellow powder; $R_{\mathrm{f}}=0.45\left(\mathrm{EtOAc} / \mathrm{EtOH} / \mathrm{H}_{2} \mathrm{O}=\right.$ $77: 15: 8) ;[\alpha]^{20}{ }_{\mathrm{D}}=-21.0(c 0.1, \mathrm{MeOH}) . \mathrm{UV}(\mathrm{MeOH}): \lambda_{\max }=$ 272, $334 \mathrm{~nm}$. IR (ATR): $v=3316,2916,2849,1916,1644$, $1609,1487,1441,1352,1243,1175,1071,1038,891,834$, 780, $616 \mathrm{~cm}^{-1} .{ }^{1} \mathrm{H}$ and ${ }^{13} \mathrm{C}$ NMR: see Table 2. ESI-MS $(+10$ $\mathrm{V}): m / z=565[\mathrm{M}+\mathrm{H}]^{+}, 587[\mathrm{M}+\mathrm{Na}]^{+}$.

\subsection{Isovitexin-7- $O$ - $\beta$-D-glucoside (Saponarin) (6)}

Light yellow powder; $R_{\mathrm{f}}=0.25\left(\mathrm{EtOAc} / \mathrm{EtOH} / \mathrm{H}_{2} \mathrm{O}=\right.$ 77:15:8); UV (MeOH): $\lambda_{\max }=272,332 \mathrm{~nm}$. IR (ATR): $v=$ $3357,2922,2852,1970,1660,1631,1571,1468,1411$, $1179,1078,899,793,719,646,629,616 \mathrm{~cm}^{-1} .{ }^{1} \mathrm{H}$ and ${ }^{13} \mathrm{C}$ NMR: see Table 2. ESI-MS $(+10 \mathrm{~V}): m / z=595[\mathrm{M}+\mathrm{H}]^{+}, 617$ $[\mathrm{M}+\mathrm{Na}]^{+}$.

\section{CONCLUSION}

We have isolated six flavonoid glycosides from the aerial parts of the Mongolian medicinal plant Polygonatum odoratum (Mill.) Druce: isorhamnetin-3-O-rutinoside (1), kaempferol-3-O-rutinoside (2), quercetin-3-O-rutinoside (3), apigenin-6- $C$ - $\beta$-D-glucoside (4), apigenin-6- $C$ - $(2$ "'- $O-\beta$-Dxylopyranosyl- $\beta$-D-glucopyranoside) (5), and isovitexin-7- $O$ $\beta$-D-glucoside (6). Five of these compounds (1-5) have been isolated from $P$. odoratum for the first time. The unequivocal structural assignment for the flavonoid glycosides 1-6 is based on extensive NMR spectroscopic investigations $\left({ }^{1} \mathrm{H}\right.$, ${ }^{13} \mathrm{C}$, COSY, HSQC, HMBC, NOESY, and ROESY). Biologically active flavonoid glycosides are frequently found in diverse plant sources [34-36]. The isolation of the bioactive flavonoid derivatives 1-6 from $P$. odoratum may help to explain the pharmacological properties of this Mongolian medicinal plant.

\section{CONFLICT OF INTEREST}

The authors confirm that this article content has no conflict of interest.

\section{ACKNOWLEDGEMENTS}

We wish to thank Dr. Ingmar Bauer and Mrs. Ljubow Rößler for measuring the ESI-MS spectra. We are indebted to Dr. Enebish Ganbold at the herbarium of the Ulaanbaatar Institute of Botany, Mongolian Academy of Sciences, for the identification of the plant. C. G. is grateful to the Deutscher Akademischer Austauschdienst (DAAD) and the Gesellschaft von Freunden und Förderern der TU Dresden (GFF TU Dresden) for providing scholarships.

\section{SUPPLEMENTARY INFORMATION}

Copies of the ${ }^{1} \mathrm{H},{ }^{13} \mathrm{C}$, and $2 \mathrm{D}$ NMR spectra (COSY, HSQC, HMBC, NOESY, and ROESY) of the compounds 16.

Supplementary information is available on the publishers web site along with the published article. 


\section{REFERENCES}

[1] Grubov, V.I. Key to the Vascular Plants of Mongolia, Gan Print Co. Ldt., Ulaanbaatar, 2008; p. 80.

[2] Wujisguleng, W.; Liu, Y.; Long, C. Ethnobotanical review of food uses of Polygonatum (Convallariaceae) in China. Acta Soc. Bot. Pol., 2012, 81, 239-244.

[3] Ligaa, U.; Davaasuren, B.; Ninjil, N. Medicinal Plants of Mongolia Used in Western and Eastern Medicine; JKC Printing: Ulaanbaatar, 2006; pp. 246-247.

[4] Janeczko, Z.; Jansson, P.E.; Sendra, J. A new stereoidal saponin from Polygonatum officinale. Planta Med., 1987, 53, 52-54.

[5] Qin, H.L.; Li, Z.H.; Wang, P. A new furostanol glycoside from Polygonatum odoratum. Chin. Chem. Lett., 2003, 14, 1259-1260.

[6] Lin, H.W.; Han, G.Y.; Liao, S.X. Studies on the active constituents of the Chinese traditional medicine Polygonatum odoratum (MILL.) Druce. Acta Pharm. Sin., 1994, 29, 215-222.

[7] Morita, N.; Arisawa, M.; Yoshikawa, A. Studies on medicinal resources. XXXVIII. Studies on constitutents of Polygonatum plants (Liliaceae) (1). The constitutents from the leaves of Polygonatum odoratum (Mill.) Druce var. Pluriflorum (Mig.) Ohwi. Yakugaku Zasshi, 1976, 96, 1180-1183.

[8] Rafi, M.M.; Vastano, B.C. Identification of a structure specific Bcl2 phosphorylating homoisoflavone molecule from Vietnamese coriander (Polygonatum odoratum) that induces apoptosis and G2/M cell cycle arrest in breast cancer cell lines. Food Chem., 2007, 104, 332-340.

[9] Wang, D.; Li, D.; Zhu, W.; Peng, P. A new C-methylated homoisoflavanone and triterpenoid from the rhizomes of Polygonatum odoratum. Nat. Prod. Res., 2009, 23, 580-589.

[10] Zhang, H.; Yang, F.; Qi, J.; Song, X.-C.; Hu, Z.-F.; Zhu, D.-N.; Yu, B.-Y. Homoisoflavonoids from the fibrous roots of Polygonatum odoratum with glucose uptake-stimulatory activity in 3T3-L1 adipocytes. J. Nat. Prod., 2010, 73, 548-552.

[11] Bai, H.; Li, W.; Zhao, H.; Anzai, Y.; Li, H.; Guo, H.; Kato, F.; Koike, K. Isolation and structural elucidation of novel cholestane glycosides and spirostane saponins from Polygonatum odoratum. Steroids, 2014, 80, 7-14.

[12] Markham, K. R. Techniques of Flavonoid Identification; Academic Press: London, 1982.

[13] Yadava, R. N.; Yadav, P. Isolation and characterization of two new compounds from Phaseolus trilobus Ait. Am. J. Phytomed. Clin. Ther., 2013, 1, 672-680.

[14] Gaffield, W.; Horowitz, R. M.; Gentili, B.; Chopin, J.; Bouillant, M.-L. Circular dichroism of C-glycosylflavones: a chiroptical method for differentiating 6- $C$-, $8-C$ - and 6,8-di- $C$ - $\beta$-glycosyl isomers. Tetrahedron, 1978, 34, 3089-3096.

[15] Tang, Y.P.; Yu, B.; Hu, J.; Wu, T.; Hui, H.Z. Three new homoisoflavanone glycosides from the bulbs of Ornithogalum caudatum. J. Nat. Prod., 2002, 65, 218-220.

[16] Rastrelli, L.; Saturnino, P.; Schettino, O.; Dini, A. Studies on the constituents of Chenopodium pallidicaule (Cañihua) seeds. Isolation and characterization of two new flavonol glycosides. J. Agric. Food Chem., 1995, 43, 2020-2024.

[17] Hyun, S.; Jung, Y.; Chung, H.; Jung, H.; Choi, J. Isorhamnetin glycosides with free radical and $\mathrm{ONOO}^{-}$scavenging activities from the stamens of Nelumbo nucifera. Arch. Pharm. Res., 2006, 29, 287-292.

[18] Salem, J. H.; Chevalot, I.; Harscoat-Schiavo, C.; Paris, C.; Fick, M.; Humeau, C. Biological activities of flavonoids from Nitraria retusa (Forssk.) Asch. and their acylated derivatives. Food Chem., 2011, 124, 486-494.

[19] Mabry, T.J.; Markham, K.R.; Thomas, M.B. The Systematic Identification of Flavonoids; Springer-Verlag: Berlin, 1970.
[20] Kazuma, K.; Noda, N.; Suzuki, M. Malonylated flavonol glycosides from the petals of Clitoria ternatea. Phytochemistry, 2003, 62, 229-237.

[21] Yoon, H.-R.; Han, H.-G.; Paik, Y.-S. Flavonoid glycosides with antioxidant activity from the petals of Carthamus tinctorius. $J$. Appl. Biol. Chem., 2007, 50, 175-178.

[22] Ahmad, M.; Gilani, A.; Aftab, K.; Ahmad, V.U. Effects of kaempferol-3-O-rutinoside on rat blood pressure. Phytother. Res., 1993, 7, 314-316.

[23] Abraham, L.C.N.; Masakuni, T.; Isao, H.; Hajime, T. Antioxidant flavonoid glycosides from the leaves of Ficus pumila L. Food Chem., 2008, 109, 415-420.

[24] Shie, J.-J.; Chen, C.-A.; Lin, C.-C.; Ku, A.F.; Cheng, T.-J.R.; Fang, J.M.; Wong, C.-H. Regioselective synthesis of di- $C$-glycosylflavones possessing anti-inflammation activities. Org. Biomol. Chem., 2010, 8, 4451-4462.

[25] Ersöz, T.; Harput, Ü.Ş.; Saracoglu, İ.; Çalis, İ.; Ogihara, Y. Phenolic compounds from Scutellaria pontica. Turk. J. Chem., 2002, 26, 581-588.

[26] Luzzatto, T.; Golan, A.; Yishay, M.; Bilkis, I.; Ben-Ari, J.; Yedidia, I. Priming of antimicrobial phenolics during induced resistance response towards Pectobacterium carotovorum in the ornamental monocot calla lily. J. Agric. Food Chem., 2007, 55, 1031510322.

[27] Fu, Y.; Zu, Y.; Liu, W.; Hou, C.; Chen, L.; Li, S.; Shi, X.; Tong, M. Preparative separation of vitexin and isovitexin from pigeonpea extracts with macroporous resins. J. Chromatogr. A, 2007, 1139, 206-213.

[28] Folador, P.; Cazarolli, L.H.; Gazola, A.C.; Reginatto, F.H.; Schenkel, E.P.; Silva, F.R.M.B. Potential insulin secretagogue effects of isovitexin and swertisin isolated from Wilbrandia ebrac teata roots in non-diabetic rats. Fitoterapia, 2010, 81, 1180-1187.

[29] Kwon, D.-J.; Kim, J.-K.; Ham, Y.-H.; Bae, Y.-S. Flavone glycosides from the aerial parts of Lespedeza cuneata G. Don. J. Korean Soc. Appl. Biol. Chem., 2007, 50, 344-347.

[30] Rayyan, S.; Fossen, T.; Anderson, M. Flavone $C$-glycosides from leaves of Oxalis triangularis. J. Agric. Food Chem., 2005, 53, 10057-10060.

[31] Otsuka H.; Kijima, K. An iridoid gentiobioside, a benzophenone glucoside and acylated flavone $C$-glycosides from Tripterospermum japonicum (Sieb. et Zucc.) maxim. Chem. Pharm. Bull., 2001, 49, 699-702.

[32] Markham K.R.; Mitchell, K.A. The mis-identification of the major antioxidant flavonoids in young barley (Hordeum vulgara) leaves. Z. Naturforsch., 2003, 58c, 53-56.

[33] Zinsmeister, H. D.; Anhut, S.; Mues, R. Roth Collection of Natural Products Data: Concise Descriptions and Spectra, Roth, L; Rupp, G; ed., Weinheim: VCH, 1995; pp. 288-292.

[34] Bhattacharya, S.; Christensen, K.B.; Olsen, L.C.B.; Christensen, L.P.; Grevsen, K.; Færgeman, N.J.; Kristiansen, K.; Young, J.F.; Oksbjerg, N. Bioactive components from flowers of Sambucus nigra L. increase glucose uptake in primary porcine myotube cultures and reduce fat accumulation in Caenorhabditis elegans. J. Agric. Food Chem., 2013, 61, 11033-11040.

[35] Mihajlovic, L.; Radosavljevic, J.; Burazer, L.; Smiljanic, K.; Cirkovic Velickovic, T. Composition of polyphenol and polyamide compounds in common ragweed (Ambrosia artemisiifolia L.) pollen and sub-pollen particles. Phytochemistry, 2015, 109, 125-132.

[36] Petpiroon, N.; Suktap, C.; Pongsamart, S.; Chanvorachote, P.; Sukrong, S. Kaempferol-3-O-rutinoside from Afgekia mahidoliae promotes keratinocyte migration through FAK and Rac1 activation. J. Nat. Med., 2015, 69, 340-348.

Received: March 30, 2015
(C) Ganbaatar et al.; Licensee Bentham Open.

Revised: June 30, 2015

Accepted: July 02, 2015

This is an open access article licensed under the terms of the Creative Commons Attribution Non-Commercial License (http://creativecommons.org/licenses/by-nc/3.0/) which permits unrestricted, non-commercial use, distribution and reproduction in any medium, provided the work is properly cited. 